Received Date : 24-Jun-2016

Accepted Date : 15-Jul-2016

Article type : Original Article

Corresponding Author E-Mail ID: v.gunn@gsa.ac.uk

\title{
Prophetic Nomadism: \\ An Art School sustainability-oriented educational aim?
}

Vicky Gunn

\begin{abstract}
:
This discursive article proposes that the learning and teaching regimes provided within Art School are uniquely placed within higher education to foster nomads. It suggests, however, that nomadism is not enough. Rather it emphasizes that to reconcile Art and Design education with sustainability, such nomadism needs both to be prophetic and collaboratively based. Prophetic nomads are defined here as mobile, social influencers able to change perspectives through calling forward uncomfortable awakenings. They achieve this by creatively reframing what is at stake if we continue to act and be as we are. The presentation will explore the similarities between key concepts in the literacy of sustainability and the elements of prophetic nomadism. It will challenge us to reconsider these in the light of their potential generation through three ingredients of learning within Art and Design: reason, aesthetics, and making. It will finish by declaring that as educators we should have the courage to more formally craft our pedagogies to call forth (evoke) and push-out (provoke) sustainabilityoriented creativity through these domains.
\end{abstract}

\section{Keywords:}

Art School Education, sustainability, creative agency, Prophetic Nomadism, Higher Education

"Day 86: Paradise is a place over the next hill."

Anthony Schrag,

The Art Pilgrimage Blog: The Lure of the Lost, September 29, 2015.

\section{Introduction:}

This paper enlists theological and historical scholarship regarding the holy nomads, Harlots of the Desert (Ward, 1987), to provide both a human face to conceptualisation of sustainability within Art School education, and to animate a metaphor of prophetic nomadism as an aspirational outcome for Art School programmes. Prophetic nomads are defined here as mobile, social influencers. They are able to change perspectives by calling forward uncomfortable awakenings via making, thinking, and doing, that reframes what we see about our engagement with the environment. Prophetic nomadism in this context is a metaphor for creative agency. 
From my background in early Church history and practical theology, I have been drawn to reimagining through story-telling, visualisation, and historical narratives in a manner that enables exploration of contemporary theological conflicts. My practice has been to use simultaneously late antique and medieval texts and contemporary visual art images with groups to disrupt accepted views of how to understand doctrinal beliefs (Gunn, 2007). This paper extends what began as an Arts and Humanities' praxis to the field of creative Arts education. In particular, it attempts to demonstrate how the practice might influence our answers to what an Art School education should be in relation to the significant environmental imperative of the Twenty-first century. I do this for two main reasons: Firstly, Sustainability as a general higher education agenda requires creative interdisciplinary approaches to facilitate disciplinary curriculum incorporation; Secondly, Arts education as a subject of analysis, like theology, has a practical as well as theoretical side and is predicated on firm beliefs about what it is and how it should operate. Quasi-doctrinal collective assumptions often underpin such beliefs and some of these assumptions generate dissonance in students and staff artists and designers alike, especially when brought into relationship with opinions and research concerning ecological environmentalism. Unpicking these locations of dissonance in the face of lived experiences and ways of learning is, like practical theology, an applied Arts activity as much as it is a psychological science. Indeed, I have found that facilitating workshops using historical metaphors reinterpreted through visual imagery, and then discussed with contemporary artists, provides a safe intellectual space for interrogating ideas about orthodoxies that have become ossified (See for example, Gunn \& Schrag, 2016).

I will argue that the harlots of the desert provide five core concepts (creativity and originality, awareness of power-dynamics, speculative pragmatism, socio-economic radicalism, ungovernability except through appropriation) which underpin the metaphor of prophetic nomadism and that these concepts correspond to literacies associated with sustainability. I will compare these characteristics to an emerging environmental Arts movement and demonstrate how, when woven together, they might provide Art Schools with a set of graduate attributes. What is unique about these attributes is that they challenge the more typically instrumentalist and anticipated-employment focused lists of outcomes increasingly attached to creative Arts' higher education as seen within the AngloAustralian-American higher educational axis.

\section{Who are the Harlots of the Desert?}

The Harlots of the Desert are represented in a series of Syria-Palestine and north African texts dated to between the third and the sixth centuries of the Common Era (C.E.) (Ward, 1987; Karras, 1990). The lives of Pelagia of Syria, Mary of Egypt, and Thais of Alexandria follow a conversion narrative, an awakening, which in some cases changes how they dressed as demonstration of this 
transformation, and in all cases leads to a renunciation of conspicuous consumption. The narratives of these women's nomadic lives have certain elements in common, particularly:

- Creativity and Originality: the transformative and disruptive social and political radicalism they presented to contemporaries through the choices they took, the gender-subversive manner in which they lived, how they came to be visualized in narrative and artistic forms (See, for example, de Certeau, 1992, Miller, 1998; Castelli, 2004; Grafton \& Williams, 2006, Harper, 2013).

- Awareness of power-dynamics: the extent to which they managed the social and power networks of their eras. This was expressed creatively, particularly in terms of gender cross-dressing, a form of performativity that enabled the redressing of certain gender inequalities at the same time as access to powerful institutions (Coon, 1997: Karras, 2005).

- Futurism via speculative pragmatism: the future-facing nature of their lives (from sinful women to elevated saints) which embodied a principle of being able to assess potential but 'empirically unverifiable futures, make them already be felt, seen, and heard in the here and now' (Gielen, $2014,24)$ and, more directly comparable with sustainability literacies, work towards the most desirable ones through trade-offs and persistence in the face of, at times, insurmountable challenges (Ward, 1987; Coon, 1997; Adams, 2001; Matzdorf \& Müller, 2010; Allen, 2015).

- Socio-economic radicalism: the potential to revision these women as living in harmony with desert lands and in so doing eschewing conspicuous consumption via an embodied form of humility. Through what was essentially a radical approach to contemporary socio-economic mores, the desert became creatively turned (through visualization) into a spiritual landscape which embodied religious perspectives at odds with mainstream society (Goehring, 2005). In such a context, thought, deed, and aesthetics worked together to create social change;

- Ungovernable except through textual / visual appropriation: These women, represented as heroines of repentance by those attempting to establish orthodox routes to salvation (Harper, 2013), are so much more than that. As a group of powerful women, successful prostitutes, embellished with a fervour for their profession that shames the contemporary clergy of their time, they are also only governable in terms of the way they come to be represented. Underneath the orthodox rhetoric and visualisation that came to dominate, it is possible to infer a much more anarchic nature.

\section{What is the method used for this paper?}

This article interlaces several intellectual strands from within the humanities, the visual arts, and the social sciences. To demonstrate why prophetic nomadism is a useful metaphor in the context of sustainability as an educational aim, the discussion here: 
- Connects the harlots of the desert lives to a current emergent visual arts movement whose creative genesis is in nomadism, and identifiable sustainability literacies (predicated on social sciences research) to generate attributes that could be associated with sustainability as an outcome of an Art School education.

- Moves onto education philosophy to explore why Art School pedagogies may be more likely to foster the attributes associated with prophetic nomadism than other higher education pedagogies.

- Suggests that Art Schools should be more courageous in identifying aspirational sustainabilityoriented graduate attributes. These attributes could link creative practices and sustainability through metaphors underpinned by theoretical and relational configurations not limited to either those only embodying disciplinary specialism or the creative industries' more socio-economic, genericist agendas.

Out of this method comes a proposition with four integrated parts:

1. Firstly, drawing on the lives of the Harlots of the Desert, the key concepts behind prophetic nomadism can be defined as creativity and originality, awareness of power-dynamics, futurism via speculative pragmatism, socio-economic radicalism, and ungovernability except through appropriation;

2. Secondly, these concepts, through a comparison with modern day prophetic nomadism represented here by such artists as Anthony Schrag and Tamar Ettun, can be extended to include interdependency and collaboration;

3. Thirdly, these concepts, when amalgamated and explored through the lens of environmentalism, align with sustainability literacies and as such offer a graduate attributes' list that captures simultaneously the potentially disruptive spirit of an Art School education and ecological environmentalism.

4. And finally, the peculiarity of the Art and Design methods which condition our students' learning make them a particular match for developing understanding of both the concepts and their respective expressions.

As a method, this approach fits within a wider movement to draw applied responses from history, theology, and philosophy to present day issues and towards using visual arts and humanities to challenge social injustice (Chazelle, Doubleday, Liftshitz \& Remensnyder, 2012; Babel Working Group).

\section{Why Prophetic Nomadism rather than just nomadism?}

The nomad has emerged as a meaningful metaphor in theories which outline how we might reenvisage future, more sustainable relationships between ourselves and our environments. It has 
offered post-humanism, in particular, a way of challenging the dominant perspectives behind takenfor-granted human consumption and the forms of imperialism that have run alongside it (Braidotti, 1994; 2006). The migratory nature of nomadic hunter gathering, even when elements of more sedentary farming are also included, evince an ideal of living lightly on the land, of cherishing what is available in a manner that enables cyclical regeneration. This migratory movement provides us with a coherent narrative with which to challenge the husbanded over-exploitation of what the earth offers up. Such movement is core to revisiting the world from the perspective of cherishing all resources as: local, immediately impactful, and needing regular replenishment. It also invokes non-Westernised indigenous traditions which emphasize the spiritual and practical interdependences of peoples and the land (Longchar, 2013). In this land, power, identity, and well-being (both societal and physical) are tightly interwoven. In its coherence, the metaphor of the nomad is powerful.

Likewise it has become a resonant metaphor for contemporary artists and designers grappling with impermanence and movement as locations of social, cultural and ecological justice. Indeed, this is a thread that links various art and design practices (from static sculpture to corporeal installations) geographically dispersed across the Globe. Nomadism is explicitly named by some artists, such as Matthew Dalziel and Louise Scullion's Nomadic Boulders (2015). In others an inherent narrative of movement leaves it inferable (Alfrey, Daniels \& Sleeman, 2016). Newer modalities of art too are considered nomadism in art practice, such as the work undertaken by the Raqs Media Collective (Bernardini, 2007).

Yet, simply being a nomad is not enough to challenge present concerns in terms of sustainability. Firstly, an ecological comprehension may seem inferable because such communities appear less destructive of nature. This is not the same as either an explicitly manifested ecological ethic which is scaleable or easily transferable to different situations or a community resistant to the uncritical adoption of technology with all it seems, in the short term at least, to promise. Secondly, for nomadism to work as an explicitly ecologically ethical way of life, it needs to alert us to the uncomfortable individual and collective responsibility essential to effecting environmental change for the better. Thirdly, as the refugee crisis increasingly reminds us, nomadic experience based on enforced movement is just exhausting survival (Gielen, 2014). Like the prophetic imagination, our art and design nomads need to 'reframe what is at stake in chaotic times' (Brueggemann, 2001). Nomadism needs to be tempered with a prophetic imperative and in this it is 'a productive-conflictive relationship' (Anthony Schrag quoted in Benmakhlouf, 2015, p. 22).

We can perceive from action, design, impact, and reflection by the artists on their art practice the prophetic nature of the nomadism they enact. Tamar Ettun's three-part performance installation piece, One Thing Leads to Another (2013) and Anthony Schrag's, expressive walk from Huntly in Scotland 
to the Venice Biennale: Lure of the Lost: A Contemporary Pilgrimage (2015) arguably embody Pascal Gielen's situational ethics (Gielen, 2014). Their art practices apply and express imagination to produce new situations which generate social support for perspectives which dynamically disrupt apparent 'givens' within a culture. These artists and practitioners are our modern day harlots of the environmental desert that is being created in large part by human interaction with Earth. What links their practices to the Late Antique harlots is their embedding of creativity and originality, awareness of power-dynamics, futurism via speculative pragmatism, socio-economic radicalism, ungovernability except through appropriation, but also two other core literacies associated with sustainability: interdependency, and collaboration:

- Interdependency: being able to comprehend how apparently immaterial as well as material systems interact to produce material systemic impact recognises the holistic, more than the sum of its parts nature of the relationships between people and their environments. It amplifies the need to grasp a notion of 'oneness' and stresses the limitations of mechanistic thinking. From the perspective of the digital media-based environmental ethicist, Carol Gigliotti, it also demands engagement with the interdependences between human creativity and non-human creativity organic, ecological, and biological (Gigliotti, 2008, 63).

- Collaboration: For sustainability, a commitment to conscious collaboration is a core literacy. This collaboration is not necessarily static in terms of its component actors or linear in terms of problem-solving. In effect, the need for collaboration which sustainability demands of us requires the simultaneous reconciliation of many principles and duties. It requires three interrelated aspects:

1. Collectivism and respect for the individual to operate as constant transactions. Mary Midgley's reflections on the environmental movements of the 1980s and 90s are instructive here. Concern for the whole and concern for individuals were shown to be simply not alternatives (Midgley, 2003: 157). Whilst complementary, however, it is also clear that environmental sustainability endeavours are 'cursed' with the dilemma of the best solution for an individual not necessarily being the best solution for a group (Waring \& Tremblay, 2015);

2. A level of specialist knowledge to interact with non-specialist and practical knowledges in a manner that values the different types of reason that specialists and non-specialists might manifest. As the scientific, technological, and ethical approaches become increasingly specialist, the content needs to be addressed less by individual polymaths and more through collaborative activity across specialisms and professions. This requires a degree of wisdom and a duty to accept complementary ways of thinking, doing and making. (See: Selin, 2015 for an example of how this might be implemented through educational practice.);

3. The reconciliation of ecological dynamics and economics, which are experienced as relatively externally-driven abstractions for people, with cultural and social mechanisms and processes 
that operate as more internally driven, less abstract, and are tied into identity construction, beliefs and preferences (See Waring \& Tremblay, 2015).

Placed together, these examples demonstrate that our prophetic nomads not only need to be collaborative but also be skilled in conflict and paradox management.

Such prophetic nomadism is about imagining interactions with environments in a way that is more than simplistically embodying utopian perceptions of the past. Putting things back to what we envisage they once were will not do. We should have no desire to re-assemble the poverty of previous eras in a romanticised way (Monbiot, 2013, 7). And here I would interpret poverty as going beyond socio-economic terms, to include political, spiritual, and ethical poverty also. It is also about more than becoming disconnected from or uncritically rejecting of our large urban centres and the agriculture, science, and technology on which they depend. As the German artist and designer, Winfried Baumann demonstrates, our nomads are just as much civic as they are rural or desert based. Unlike our holy harlots, our prophetic nomads cannot retreat to a wilderness. They are needed in the cities.

Prophetic nomadism represents a provocative call to human communities: We need to be actively awoken to both the personal and political conditions of our current socio-environmental status. In terms of the personal condition we must be consciously mindful, as Monbiot notes, that: "The amplification of our lives by technology grants us the power over the natural world which we can no longer afford to use...We may no longer live as if there were no tomorrow." (Monbiot, 2013, 7). Carol Gigliotti captures the political condition as finding ways to challenge "the elite global networks of political, military, and business people" that operate and exploit without cherishing the world's resources (Gigliotti, 2008, 61). And, perhaps more uncomfortably, finding ways to challenge and offer suitable alternatives to the argument for a 'greater good' from which this operation and exploitation often occurs. This is a hard wake up call to set. Its alert will not come from nomadism alone, it will need to be a nomadism that functions prophetically.

\section{Connecting the Prophetic Nomad Metaphor, Art Schools, and Sustainability?}

The sustainability agenda is a recognised pedagogic challenge for higher education. This is certainly the case for the creative disciplines where views about embedding ecological environmentalism in Art School curricular can oscillate between either too abstract from the discipline (Kleiman, 2010) or a potential threat to autonomous creativity (Gielen, 2014). Perhaps, however, what we should address is how Visual Arts education might prepare students to simultaneously consider sustainability as something requiring more than a canon of knowledge and authentic creativity as being drawn from within themselves in the light of a critical awareness of the disruptive attributes they can bring, through their making, doing, thinking to their social contexts. That is, to express the characteristics of 
prophetic nomads through Art and Design in a manner that evokes social change concerning our relationship with resources, climate, and hopes for the future.

If this is our point of departure, Art Schools might be particularly well equipped to develop the characteristics of prophetic nomads because of the unique nature of their learning and teaching 'ecology'. This learning and teaching ecology arguably, marshalls together particularly methods of reason, aesthetics, technical ability, and the connective and open-ended play inherent in making into studio-centred activities that influence, if not condition, what and how our students learn:

\section{Methods of Reason}

The nature of an Art School education, with its mix of theory and practice at the same time as its deliberative approach of unstructured structure as an organizing principle behind the curriculum, means that undergraduates encounter a broader range of methods of reason than they might otherwise in universities. In his work of the 1930s, drawing on the American pragmatist, Charles Sanders Peirce, John Dewey acknowledged this, especially regarding inductive, deductive, and abductive reasoning and his recognition has been influential in the articulation of the pragmatic quality of design thinking (Dalsgaard, 2014). Abductive reasoning emphasizes the interconnectedness of apparently irrelevant materials/ ideas in order to make a different or bigger sense of design situations. In this it amplifies systems' thinking because to make meaning requires understanding the relationality of meanings and values within and across the given situation. This is most obviously seen when designers bind seemingly unrelated objects to a project or design in a speculative manner and from this generate a novel object or idea. Referred to by designers as speculative pragmatism, this is a nonarbritary, embodied skill (Kolko, 2010; Manning \& Massumi, 2014). Arguably, its presence in response to studio-based projects is a necessary condition for futurism, forethought, and nonconventional approaches which recognise the interrelatedness of objects and activities within given systems.

This triad has been extended by artists in their discussion of the pre-discursive nature of art, referred to variously as the 'space of the unthought', the postponement or rerouting of theory, and the 'anticipatory before knowing' or 'knowing as movement' (Borgdorff, 2012; Ingold, 2013). Intrinsically linked to making, it cannot be contained by closed circuits of thinking: "It makes its own rules" (Borgdorff, 2012, p. 70-71). The critical point is, the balance of methods of reasoning in Art and Design compel us to move beyond replicating convention in a manner that inductive and deductive methods alone often do not. Pre-discursive and abductive reasoning in particular are hard to govern, whereas inductive and deductive reasoning contain properties that lend themselves to conventional measurement and control. Creativity and originality 'arise out of the tension between 
the rules and imagination' (Hodder, 1998, p. 62) and this disruption of conventional thinking is an essential characteristic of prophetic nomadism.

\section{Aesthetics and affect}

Disciplinary learning and teaching regimes are sensory and material rather than disembodied. Their aesthetics is both felt and structured in terms of appreciation and judgement together, that is affective response and self-explanation/ representation of what is perceived occurs rapidly (Prinz, 2011). Thus aesthetics, in its broadest definition as the subjective leaning towards or away from an idea, object, or activity of an observer (as well as methods of reason) within an inter-subjective network, influence the what and the how of learning. Yet, in analysis of university student learning they are a startling omission. Art School environments, however, claim to embed aesthetics both implicitly through aspects of making and doing and explicitly through conversational reflection (in formal Crits and informal peer-to-peer activity) and engagement with theory. For the purposes of this paper, I would like to argue that ecological awareness and the environmental systems' dynamics it demands are as much a matter of aesthetics as they are of reason. Malcolm Miles has summed this up by noting that as a sensing subject, the spectator may constitute the land either as an object (apart from self) or as a subject mirroring her or his own state (Miles, 2014, p. 49). If the former is stressed, it is too easy to see immediate needs without recognising how what we do with these needs has to be placed within a holistic approach. Arguably, given Marxist and post-modernist concern about aesthetics (O'Sullivan, 2001), sustainability establishes a tension for how we foster aesthetic depth in our students. On the one hand, we need to evoke the immediacy, participation, and desire of everyday aesthetics (Duncum, 1999) likely to cultivate a relational process with our students' audiences in order to build social change, whilst on the other developing an aesthetic expertise which actually emphasises delay of gratification and a cultivation of a discerning awareness of how ecological systems work. The intense here and now of affect (with its power to lean us towards objects and ideas) and deliberative, informed judgement need to work together rather than as a dialectic. Prophetic nomadism within the context of ecological environmentalism means generating an aesthetic wisdom more broadly in society. Such a wisdom manifests the paradoxical coexistence of these two aspects, rather than the rhetorical oppositional binary of 'everyday' and 'elite' that has dominated the powerful critiques of aesthetics in the second half of the Twentieth Century (O'Sullivan, 2001).

\section{Technical ability: Making material and immaterial}

The embodied nature of making is emphasized within Art School pedagogies, be that the creation of objects physical and virtual (artefact-making) or the creation of ideas (meaning-making). The role of practical wisdom in craft and how making is connecting is an amplified aspect of Art School education particularly when compared with other forms of university education (Sennett, 2008; Gauntlett, 2011). What is clear is that how we make shapes both materials and our minds (Malafouris, 2013). Making also reveals the messy, unpredictability behind the creation of the real 
(Ingold, 2013: 59), including the potential to pollute in our own drive to innovate (Papanek, 1985). When brought into enforced critical conversation with multiple methods of reason and aesthetics, making provides an opportunity for growing humility within the creative expression of our curiosity and desire to control. Like aesthetics, however, making and one of the new-materialist ways of understanding it (Barrett \& Bolt, 2013), is only slowly entering research on how students learn in higher education. Yet, arguably materiality is the genesis point of prophetic nomadism: making and the experimentation that accompanies it within a nature imperative, "emphasizes the critical role of artists and designers in exploring, interpreting, and representing nature's teaching to share values that embrace living systems on Earth" (Overstrom, 2013: 207)

At its best then, an Art School education amplifies the possibilities of challenging and original action (referred to throughout this paper as: creative agency). It does this through its reiterative weaving of potent educational influencers whose foundations can be summed up as follows: reframing perceptions and their influence on imagination, critical idea expression, and materials comprehension to create and have that creativity received within a relationship (ie aligned to Bourriaud's relational aesthetics (2002) and explored as a conflation of aesthetic education and utopian pedagogy by Clark \& Jackson, forthcoming). In essence, such agency and the creative will at its heart offers the promise of deliberate irritation (Clark \& Jackson, forthcoming) and ultimately resetting of societal norms currently upholding dominant socio-economic habits and geo-political complacencies.

\section{The limitations of the proposition}

This proposition is not without its caveats. These are offered as five points of summation here. The first one is perhaps the most emotive: Using a metaphor so intrinsically linked with one theological movement could re-engender injustices based on temporally and geographically-specific, religious movements. Indeed, these movements have been used not just to ignore environmental issues but to actively perpetuate beliefs which place the consumption of the earth's gifts within a hierarchy in which humanity, as the pinnacle of divine creation, is overlord (Bianchi, 1998; Santmire, 2000; Jurasz, 2013). Moreover, in the Harlots of the Desert metaphor used here, there is scope to interrogate the problems of using a metaphor imbued with an absolutist tendency towards a particularly religious moral sensibility which could easily become an extremist form of environmentalism. Taken to its natural conclusion, over-moralizing of this nature, with an undercurrent of the containment of sexuality as present in the lives of the late antique holy harlots, potentially closes down the creative will and appropriately lies behind fears of ideologies which harness artists and designers. To build prophetic nomadism, we will nonetheless need to understand how we facilitate awareness of the impact of our creative wills, without moralizing to such an extent that creative will within sustainability becomes a negative human aspect to be suppressed.

Additionally, whilst a form of redemptive futurism is a key component of prophetic nomadism, if this 
futurism becomes purely apocalyptic in nature or a narrative of aggressive pre-emption (Massumi, 2015), the focus of this characteristic is likely to be perverted from possibilities and pragmatism towards threats and paranoia. In this sense, how we construct our belief in the paradise over the hill will determine how prophetic nomadism operates.

The subsequent observations are about pedagogy, relating mostly to what we know about teaching and learning in higher education. Firstly, the relationships between how we teach our discipline specialisms, the environments in which our students learn, and how students develop the broader educational attributes are as yet under-determined. Moreover, there are varied educational orientations expressed by academic and practitioner based teachers in Art Schools and for some, specialist development does not always align with characteristics linked directly to sustainability. Cues given thus, can draw students away from considering bigger educational themes towards a seemingly more relevant, less abstract, specialization. Secondly, there are diverse personal convictions evident in student groups, and the extent to which engagement with and cultivation of prophetic nomadism occurs needs to be explored in the light of pre-existing orientations towards it amongst our students. Throughout a degree programme the integration of methods of reason, aesthetics, technical ability and experimentation is left to the student to pull together. It depends upon students fashioning the threads of learning in Art and Design into a coherent whole as they encounter them over the totality of a programme of study. This process is achieved via engagements in specific disciplinary activities and cultures which effect the balance of the methods of reason, aesthetic tuning, and opportunities to make to which a student is exposed. For example, whilst speculative pragmatism might be a dominant meta-narrative in Design, pre-configured action seems to play a stronger role in Art. The balance of the methods of reason that students find themselves drawn to may impact on the development of attributes. Thirdly, there is an urgent need for robust research into both the role of aesthetics and making in learning within higher education. Generally, present research centres on describing specific cognitive and phenomenographical categories, not on how the embodied ecology of a learning and teaching regime might function holistically to generate these categories in a manner that makes literacy in sustainability more likely.

\section{Conclusion}

To engage the world in environmental change requires powerful creativity. As such Art School provides a learning context in which sustainability fits as a core educational aim. This paper has introduced a way of reconciling Art and Design education to sustainability through prophetic nomadism. Such prophetic nomadism has been informed via narratives of the late antique harlots of the desert, and expanded to recognize what is missing from these stories in the light of an emerging Arts movement. From this a relevant list of potential environmentally-focused attributes were generated: creativity and originality, awareness of power-dynamics, speculative pragmatism, socio- 
economic radicalism, ungovernability except through appropriation, interdependency, and collaboration. The central argument of this paper is that Art and Design programmes are uniquely placed to cultivate these attributes, attributes which encapsulate creative agency and challenge the instrumentalism evident in other higher education sector graduate attributes' lists as they have emerged over the last decade or so.

On their own, our students as creative agents might not be able to save the world, nor should we have romantic notions about direct causal links between Visual Arts and better futures (Miles, 2014: 3; Sommer, 2014: 4). What they can do is expose contradictions, re-inflect the conditions in which Art and Design are generated (Miles, 2014, 3; Gielen, 2014), and through these actions interrupt environmentally problematic comfort zones. The approach suggested here is less about teaching ecological environmentalism as a canon of knowledge or via specific modules, and more about provoking environmental fluency as an outcome of an Art School education. If, as a sustainability metaphor, paradise is over the next hill, Arts higher education should be leading the journey.

\section{References}

Adams, W.M. (2001) Green Development: Environment and Sustainability in the Third World. $2^{\text {nd }}$ Edition. Routledge: London.

Alfrey, N., Daniels, S. \& Sleeman, J. (2016) To the Ends of the Earth: Art and Environment, Tate Papers, no. 17, Spring 2012, http://www.tate.org.uk/research/publications/tate-papers/17/to-the-endsof-the-earth-art-and-environment, accessed 28 April 2016.

Allen, K. E. (2015) Trade-offs in nature tourism: contrasting parcel-level decisions with landscape conservation planning. Ecology and Society 20(1): 21. http://dx.doi.org/10.5751/ES-07058-200121

Babel Working Group (founded in 2004): http://blogs.cofc.edu/babelworkinggroup/ Accessed $28^{\text {th }}$ April 2016

Barrett, E. \& Bolt, B. eds. (2013) Carnal Knowledge: Towards a 'New Materialism' through the Arts. I.B. Taurus: London.

Baumann, W., Urban Nomads: http://www.instant-housing.de accessed $28^{\text {th }}$ April 2016

Bernardini, E. (2007) Raqs Media Collective: Nomadism in Art Practice. In Jeffrey, C. \& Minissale, G. eds., Global and Local Art Histories. Cambridge Scholars Publishing, Newcastle. Also at: http://www.raqsmediacollective.net/images/pdf/84596231-6f50-48ed-8c41-429a03b57124.pdf

Benmakhlouf, A. (2015) Cheaper than Flying. In The Skinny, June 2015, p. 22: http://issuu.com/theskinny/docs/june-issue117/23? $=1069858 / 13263914$

Bianchi, E. C. (1998) The Ecological Challenge to Christianity. New Theology Review, 11(1): pp. 6779.

Bourriaud, N. (2002) Relational Aesthetics. Les Presses du Réel 
Braidotti, R. (1994) Nomadic Subjects. Embodiment and Sexual Difference in Contemporary Feminist Theory, New York: Columbia University Press.

Braidotti, R. (2006) Transpositions. On Nomadic Ethics, Cambridge, UK and Malden USA: Polity Press.

Castelli, E.A. (2004) Martyrdom and Memory: Early Christian Culture Making. Columbia University Press: New York.

Chazelle, C., Doubleday, S., Liftshitz, F. \& Remensnyder, A. eds. (2012) Why the Middle Ages Matter: Medieval Light on Modern Injustice. Routledge: Abingdon.

Clark, J. \& L. Jackson, Aesthetic Education and Specialist Institutions. In Hall, R. and Winn, J. (Eds.) Mass Intellectuality, Democracy, Co-operation and Leadership in Higher Education, Bloomsbury (Forthcoming 2016) - Title of chapter likely to change

Coon, L. (1997) God's Holy Harlots: The Redemptive Lives of Pelagia of Antioch and Mary of Egypt. In her: Sacred Fictions: Holy Women and hagiography in Late Antiquity. University of Pennsylvania Press: Philadelphia.

Dalziel, M. \& Louise Scullion, L. (2015) Nomadic Boulders, see: http://www.johnogroatjournal.co.uk/News/Nomadic-Boulders-sculpture-unveiled-at-John-OGroats-05112015.htm

De Certeau, M. (1992) The Mystic Fable. Chicago: Chicago University Press.

Duncum, P. (1999) A Case for an Art Education of Everyday Aesthetic Experiences. Studies in Art Education, 40(4): 295-311.

Borgdorff, H. (2012) The Conflict of the Faculties: Perspectives on Artistic Research and Academia. Leiden University Press: Leiden.

Brueggemann, W. (2001) The Prophetic Imagination. $2^{\text {nd }}$ edition. Augsburg Fortress Press: Minneapolis

Dalsgaard, P. (2014) Pragmatism and Design Thinking. International Journal of Design, 8(1): 143155.

Gauntlett, D. (2011) Making is Connecting: The social meaning of creativity, from DIY and knitting to YouTube and Web 2.0. Polity Press: Cambridge.

Gielen, P. (2014) Situational Ethics: An Artistic Ecology. In Cools, G. \& Gielen, P. eds. The Ethics of Art: Ecological Turns in the Performing Arts. Antennae Series No. 11, Valiz: Amsterdam, pp. 1840.

Gigliotti, C. (2008) Sustaining Creativity and Losing the Wild. In: Alexenberg, M. ed. Educating Artists for the Future: Learning at the Intersections of Art, Science, Technology and Culture. Intellect: Bristol: pp 61-

Goehring, J.E. (2005) The Dark Side of the Landscape: Ideology and Power in the Christian Myth of the Desert. In Martin, D. B. \& Miller, P.C. eds. The Cultural Turn in Late Ancient Studies: Gender, Asceticism \& Historiography. Durham/London: Duke University Press, pp. 136-

Grafton, A. \& Williams, M. (2006) Christianity and the Transformation of the Book. Cambridge, Massachusetts: Belknap-Harvard Press. 
Gunn, V. A. (2007) Medieval Church History and Queer Ministry: Using the Historical Imaginary to Build Theological Community, International Journal of Queer Ministry, 1:1:

http://www.queerministry.com/ Reprinted in Quest Bulletin 62 (Winter 2011-12). Open access version: http://eprints.gla.ac.uk/49307/ Accessed 28 April 2016.

Gunn, V. A. \& Schrag, A. (2016) Can Art and Design Students Change the World's Engagement with Sustainability? Talk \& Debate: GSA Sustainability. Glasgow School of Art, Glasgow, $14^{\text {th }}$ March 2016.

Hodder, I. (1998) Creative Thought: A Long Term Perspective. In Mithen, S. ed., Creativity in Human Evolution and Prehistory. Routledge: London.

Ingold, T. (2013) Making: Anthropology, Archaeology, Art and Architecture. Routledge: London.

Jurasz, I. (2013). "Nature" or "Creation"? Difficult Choices of the Church Fathers. In: Gagliardi, P., Reijnen, A.M. \& Valentini, P. eds., Protecting Nature, Saving Creation: Ecological Conflicts,

Religious Passions, and Political Quandaries. Palgrave Macmillan: New York, pp. 33-42.

Karras, R.M. (1990) Holy Harlots: Prostitute Saints in Medieval Legend. Journal of the History of Sexuality, 1(1): 3-32.

Karras, R. M. (2005) Sexuality in Medieval Europe: Doing Unto Others. Routledge

Kleiman, P. (2010) Staging Sustainability: Making sense of sustainability in higher education dance, drama and music. In Jones, P., Selby, D. \& Sterling, S. eds. Sustainability Education: Perspectives and Practice Across Higher Education. Earthscan.

Kolko, J. (2010) Abductive Thinking and Sensemaking: The Drivers of Design Synthesis. Design Issues, 26(1): 15-28.

Ettun, T. \& Lev, N. (2013) Tamar Ettun: a nomadic body? Thursday, June 27, 2013, ICI Curatorial Hub, 401 Broadway, Suite 1620, New York, NY 10013:

http://curatorsintl.org/events/tamar ettun a nomadic body Accessed 28th April 2016.

Longchar, W. (2013) Liberation Theology and Indigenous People. In Cooper, T. ed. The Emergence of Liberation Theologies: Models for the Twenty-First Century. New York: Palgrave MacMillan.

Manning, E. \& Mussami, B. (2014). Thought in the Act: Passages in the Ecology of Experience. Minneapolis: University of Minnesota.

Malafouris, L. (2013) How Things Shape the Mind: A Theory of Material Engagement. MIT Press: Cambridge, Massachusetts.

Matzdorf, B. \& Müller, 2010. Environmental, Economic and Social Trade Offs. International Conference and Workshop Salzau Castle and Kiel University June 7-11, 2010: URL: http://www.unikiel.de/ecology/projects/salzau/wp-content/uploads/2010/07/matzdorf mueller final pdf2.pdf (Last accessed 21.01.16)

Midgley, M. (2003) The Myths we Live By. Routledge: London

Miles, M. (2014) Eco-Aesthetics: Art, Literature and Architecture in a Period of Climate Change. Bloomsbury: London. 
Miller, P.C. (2005) Is There a Harlot in this Text? Asceticism and the Grotesque. In Martin, D. \& Miller, P. C. eds. The Cultural Turn in Late Ancient Studies: Gender, Asceticism, and Historiography. Duke University Press: Durham/London.

Monbiot, G. (2013) Feral. Penguin: London

Mussami, B. (2015) Ontopower: War, Powers, and the State of Perception. Duke University Press: Durham/ London.

O'Sullivan, S (2001) The Aesthetics of Affect: thinking Art beyond representation. Angelaki: Journal of the Theoretical Humanities, 6 (3): 125-

Overstrom, N. (2013) The Nature Imperative. In: Somerson, R. \& Hermano, M. eds., The Art of Critical Making. Wiley: New Jersey, pp. 190-209.

Papanek, V. (1985) Design for the Real World: Human Ecology and Social Change. Thames \& Hudson: London.

Santmire, H. P. (2000) Nature Reborn: The Ecological and Cosmic Promise of Christian Theology. Fortress Press: Minneapolis.

Schrag, A. (2015)_The Art Pilgrimage Blog: The Lure of the Lost http://www.deveron-arts.com/lure-lostcontemporary-pilgrimage/

Selin, C. (2015) Merging art and design in foresight: Making sense of Emerge [Artists and Scientists Redesign the Future]. Futures, 70: 24-35.

Sennett, R. (2008) The Craftsman. Penguin: London.

Sommer, D. (2014). The Work of Art in the World: Civic Agency and Public Humanities. Duke University Press: Durham/ London.

Ward, B. (1987) Harlots of the Desert: A Study of Repentence in Early Monastic Sources. Mowbray: Oxford.

Waring, T.M. \& Tremblay, E. (2015) An Evolutionary Approach to Sustainability Science. At: https://evolution-institute.org/focus-article/an-evolutionary-approach-to-sustainability-science/ 